\title{
Business models for telehealth in the US: analyses and insights
}

\author{
This article was published in the following Dove Press journal: \\ Smart Homecare Technology and TeleHealth \\ 22 February 2017 \\ Number of times this article has been viewed
}

\section{Francis Pereira}

Data Sciences and Operations, Marshall School of Business, University of Southern, Los Angeles, CA, USA
Correspondence: Francis Pereira Data Sciences and Operations, Marshall School of Business, University of Southern, Los Angeles, CA 90089, USA

Email pereira@marshall.usc.edu
Abstract: A growing shortage of medical doctors and nurses, globally, coupled with increasing life expectancy, is generating greater cost pressures on health care, in the US and globally. In this respect, telehealth can help alleviate these pressures, as well as extend medical services to underserved or unserved areas. However, its relatively slow adoption in the US, as well as in other markets, suggests the presence of barriers and challenges. The use of a business model framework helps identify the value proposition of telehealth as well as these challenges, which include identifying the right revenue model, organizational structure, and, perhaps more importantly, the stakeholders in the telehealth ecosystem. Successful and cost-effective deployment of telehealth require a redefinition of the ecosystem and a comprehensive review of all benefits and beneficiaries of such a system; hence a reassessment of all the stakeholders that could benefit from such a system, beyond the traditional patient-health provider-insurer model, and thus "who should pay" for such a system, and the driving efforts of a "keystone" player in developing this initiative would help.

Keywords: telehealth, business model framework, stakeholders, ecosystem, VISOR business Model

\section{Introduction}

Globally, national health sectors have been characterized by substantial and ever-increasing costs, attributable to 1) a growing shortage of doctors and nurses relative to the population; 2) increasing life expectancy of the people, ${ }^{1}$ where each additional year in life expectancy is estimated to add 3\% to total costs; and 3) greater detection of diseases by patients. Total global expenditure on health is estimated at some $\$ 6.5$ trillion in 2012. By the end of 2009, in the US alone, the health care costs totaled some $\$ 2.4$ trillion, with expenditures expected to double by the end of 2015 . While the US spends about $17.9 \%$ of gross domestic product on health care, ${ }^{2}$ many Americans were uninsured or underinsured, till Obama Care. Many communities remain medically underserved. In this respect, the solution to the ever-increasing costs may lie in preventive care, early detection care, and health maintenance, enabled by telehealth.

While the terms telehealth, eHealth, and mobile health (mHealth) are relatively new, the first uses of telemedicine date back to the 1920s, where it was used for ship to land consultations. However, even with advances in medical technology over the years, the use of telemedicine in actual patient-doctor consultations remains low. Telemedicine is generally defined as "the provision of health care through a combination of telecommunications and multimedia technologies with medical expertise" and thus includes the use of computer technologies, remote sensing and monitoring, and the use of telemetry devices. ${ }^{3}$ 
However, this paper uses the term telehealth comprehensively to include telemedicine, eHealth, and mHealth, and thus incorporates collaborative patient care, remote monitoring, and access to electronic medical databases and libraries. Many observers have long argued that telemedicine has significant potential to develop into an integral component of the global health-care system; better and more extensive access to health care could be achieved through remote sensing, collaborative patient care, and access to medical databases and electronic libraries, leading to lower medical costs and increased medical productivity. Similarly, mobile digital home-health applications can monitor individual's nutrition intake ${ }^{4}$ as well as manage chronic diseases, such as chronic obstructive pulmonary disease (COPD), diabetes mellitus, hypertension, and heart disease. Thus, mHealth comprises a specific set of telemedicine applications and is defined as the use of patient monitoring and communication applications and devices, using wireless transport technologies, to transmit patient health data and information over geographical areas.

Telehealth has the potential to address the cost pressures as well as the health availability issues facing the global health-care sector. But its (telemedicine) low adoption rate since the 1920s, despite rapid advancement, particularly in the last 5-8 years, in sensor and wireless technologies, suggests that despite the significant advantages it may offer, there may be potential differences in "business model" settings of the key players in the health industry ecosystem, especially, health-care providers and insurers, and other nontraditional players. Specifically, of the more than $\$ 400$ billion expended by Medicare in 2006, only $\$ 2$ million was spent on medical services conducted electronically. ${ }^{5}$ By 2012, while Medicare expenditures had increased to some $\$ 566$ billion, telemedicine reimbursements amounted to some $\$ 6$ million. ${ }^{6,7}$

In this paper, the VISOR (Value Proposition, Interface, Service Platform, Organizing Model, and Revenue Model) Business $\mathrm{Model}^{8}$ is adopted to identify and discuss the value proposition that telehealth offers. The components of this business model help delineate the different interests and issues that have to be considered to deploy a successful and sustainable product or service. More importantly, we use VISOR as an analytical framework to identify the barriers that need to be resolved to encourage telehealth's adoption, widespread use, and success. ${ }^{9,10}$

\section{A business model framework for analyses}

Surprisingly, while the term "business models" is commonly used in corporate strategy and is used ubiquitously in both academic and professional publications, there is however, no accepted definition of the term "business model" as many have noted. ${ }^{11}$ While the origins of the concept date back to the works of Peter Drucker, ${ }^{12}$ a business model, as an accepted framework, only became prominent in the last 20 years or so, with some observers noting the term "business model" being used particularly in industry in the 1990s during the dotcom era. However, others have argued that the concept is relatively new and traces back only to the early 1980s. In either case, the initial approach of business models had been scientific, analyzing the firm, the industry in which the firm operates, and the resources it uses, as illustrated by the works of Porter and Wernerfeld. ${ }^{13}$ But, more importantly, there was little theoretical basis in the academic literature for the concept of business models. ${ }^{14-16}$

Given the myriad of published business models, significant challenges exist to understanding the key components of a business model. This has created confusion, and the concept has been used variously to mean business model, strategy, business concept, revenue model or economic model, with these concepts often used interchangeably; the business model has been referred to as architecture, design, pattern, plan, method, assumption, and statement. ${ }^{15}$

In this respect, some authors have defined business models as "the logic of the firm, the way it operates and how it creates value for its stakeholders". ${ }^{17}$ While others use the term to define the architecture for product, service and information flows, including a description of the various business actors and their roles; a description of the potential benefits for various business actors; and a description of the sources of revenue. ${ }^{18}$

In a review of the definition of business models, the literature shows that there have been three different approaches, namely economic, operational, and strategic, each with their unique set of decision variables. ${ }^{15}$ From an economic approach, the focus is on how firms can be profitable. Here, the key components in the business model include pricing methods and strategies, sources of revenue, cost structures, profits, and sales levels. This approach outlines the current profitability of the firm and the sustainability of future revenues. ${ }^{19}$ The operational approach, on the other hand, analyzes the firm's internal procedures or processes and its infrastructure design, so as to create systems that are interdependent and can sustain its competitiveness in business. Here, the focus is on how firms create value, with key business model components that include the production setup, fulfillment and delivery systems, resource flows, administrative processes, and knowledge management. ${ }^{20}$ The strategic 
approach, in contradistinction, emphasizes the firm's marketing position, growth prospects and opportunities, and its organizational and institutional boundary interactions. Thus, the focus is on how firms identify their customer base, define and differentiate their products and services, create their customer value proposition(s), determine which processes would be outsourced or performed in-house, how their resources are configured, and ultimately, how to capture profits. ${ }^{21}$ Key business model components include value creation, stakeholder identification, value networks, and alliances. Furthermore, while properly formulated business models can be a strategic tool for a firm and prove immense value, many "business models" are prone to four common defects, ${ }^{11}$ namely, 1) untested or flawed assumptions used in the development of the key components of a firm's business plan; 2) limited consideration of the strategic choices; 3) a misunderstanding between creating value versus capturing value, leading to organizations unable to financially capitalize on the "value" they create, which then affects "revenue generation" as well as other aspects of business models negatively; and 4) flawed assumptions on the value network.

Although properly formed business models are very useful and can be a strategic tool in decision-making, and there are examples of relatively robust business models, ${ }^{11,15}$ most of these models do not specifically incorporate the role of the business ecosystem and, particularly important for digital products and services, user experiences and requirements with the access devices to these services, as summarized in Table 1.

In this respect, the VISOR Business Model strives to achieve two objectives: 1) integrate the different approaches in the literature, and the respective components of "good" business models and 2) address other important elements, specifically the user experience and interface factors, that are not explicitly incorporated in other models. However, while these factors are not used in current business models, they figure prominently in many theories of diffusion of innovations, such as Roger's “Diffusion of Innovation". ${ }^{22}$ Furthermore, with electronic or digital applications and services, as those used in telehealth, interface and service platform factors become extremely important. Fundamentally, all good business models must be able to address several key questions, Who is the customer? What does the customer value? How do we make money in this business? What is the underlying economic logic that explains how we can deliver value to the customers at an appropriate cost? ${ }^{23}$
Following the logic of good business models, the VISOR Business Model, as depicted in Figure 1, defines how a firm identifies the latent or established needs of its customers, then creates and delivers the greatest value to the customer, with profitable revenue streams both in the present and future. Essentially, in the VISOR Business Model, the cost to deliver a product or service is incurred through the Interface (for example, cost of the access device or adapting software for the devices), Service Platform (such as the cost of the networks and software), and Organizing Model (for example, the payout to partners). Revenue streams are captured by the Value Proposition (willingness to pay) and Revenue Model (the pricing structure). The VISOR Business Model thus identifies how value creation can be optimized relative to the costs. Viewed through VISOR, a successful business model is one that is able to align the respective components of the VISOR Business Model so as to deliver the greatest value proposition that maximizes the willingness to pay on the part of its target consumers, on the one hand, with the ability to minimize the real cost (tangible and intangible) of the provision of these services, the latter being achieved through the optimal mix of interface experience, service platforms, and the organizing model. ${ }^{8}$

As Figure 1 also illustrates, "weakness" in one component of the business model could be compensated by "stronger" aspects in the other components. For example, a "weak" value proposition for a digital product or service could be compensated by a stronger "organizing model" to still make the offering viable; specifically, bundling other related goods and services from partners, together with the initial product or service. Alternatively, a "strong" value proposition could accommodate weakness in the Interface or Service Platform aspects in the delivery of the product or service.

\section{Value proposition}

The "Value Proposition" measures the value customers or market segments realize from consuming a firm's product or service and captures the total benefit the customer attains from using the product or service, as measured by their willingness to pay for them. As such, it captures the "value creation" the firm's customers attain through the consumption of its products or service and which satisfies their latent demand. It can be defined in the way several questions are answered:

- Do we know what are we providing? (That is, customers do not want an MP3, they want music.)

- Do we know who we are doing it for? (Understand target customers and their unique needs.) 
Table I Comparison of business model approaches

\begin{tabular}{|c|c|c|c|c|}
\hline Authors & Components & $\begin{array}{l}\text { Number of } \\
\text { components }\end{array}$ & Ecosystem & $\begin{array}{l}\text { Digital } \\
\text { platform }\end{array}$ \\
\hline Horowitz $^{91}$ & $\begin{array}{l}\text { Price, product, distribution, organizational characteristics, } \\
\text { and technology }\end{array}$ & 5 & No & Some \\
\hline Viscio and Pasternak ${ }^{92}$ & Global core, governance, business units, services, and linkages & 5 & No & No \\
\hline Timmers $^{93}$ & $\begin{array}{l}\text { Product/service/information flow architecture, business } \\
\text { actors and roles, actor benefits, revenue sources, and } \\
\text { marketing strategy }\end{array}$ & 5 & No & Some \\
\hline Markides $^{94}$ & $\begin{array}{l}\text { Product innovation, customer relationship, infrastructure } \\
\text { management, and financial aspects }\end{array}$ & 4 & No & No \\
\hline Donath 95 & $\begin{array}{l}\text { Customer understanding, marketing tactics, corporate } \\
\text { governance, and intranet/extranet capabilities }\end{array}$ & 4 & No & No \\
\hline Mahadevan ${ }^{96}$ & Value stream, revenue stream, logistical stream & 3 & No & No \\
\hline Gordijn et al ${ }^{97}$ & $\begin{array}{l}\text { Actors, market segments, value offering, value activity, } \\
\text { stakeholder network, value interfaces, value ports, } \\
\text { and value exchanges }\end{array}$ & 8 & No & No \\
\hline Linder and Cantrell ${ }^{98}$ & $\begin{array}{l}\text { Pricing model, revenue model, channel model, commerce } \\
\text { process model, the Internet-enabled commerce relationship, } \\
\text { organizational form, and value proposition }\end{array}$ & 8 & No & Some \\
\hline Chesbrough and Rosenbaum ${ }^{99}$ & $\begin{array}{l}\text { Value proposition, target markets, the internal value chain } \\
\text { structure, cost structure and profit model, value network, } \\
\text { and competitive strategy }\end{array}$ & 6 & No & No \\
\hline Gartner ${ }^{100}$ & $\begin{array}{l}\text { Market offerings, competencies, core technology } \\
\text { investments, and bottom line }\end{array}$ & 4 & No & Some \\
\hline Hamel $^{101}$ & $\begin{array}{l}\text { Core strategy, strategic resources, value network, } \\
\text { and customer interface }\end{array}$ & 4 & No & No \\
\hline Petrovic et al ${ }^{102}$ & $\begin{array}{l}\text { Value model, resource model, production model, } \\
\text { customer relations model, revenue model, capital } \\
\text { model, and market model }\end{array}$ & 7 & No & No \\
\hline Dubosson-Torbay et al $^{103}$ & $\begin{array}{l}\text { Products, customer relationship, infrastructure } \\
\text { and network of partners, and financial aspects }\end{array}$ & 4 & No & Some \\
\hline Afuah and Tucci ${ }^{104}$ & $\begin{array}{l}\text { Customer value, scope, price, revenue, connected } \\
\text { activities, implementation, capabilities, and sustainability }\end{array}$ & 8 & No & Some \\
\hline Weill and Vitale ${ }^{105}$ & $\begin{array}{l}\text { Strategic objectives, value proposition, resource sources, } \\
\text { success factors, channels, core competencies, customer } \\
\text { segments, and IT infrastructure }\end{array}$ & 8 & No & No \\
\hline Applegate ${ }^{106}$ & Concept, capabilities, and value & 3 & No & No \\
\hline Amit and Zott ${ }^{107}$ & $\begin{array}{l}\text { Transaction content, transaction structure, and } \\
\text { transaction governance }\end{array}$ & 4 & No & No \\
\hline Alt and Zimmerman ${ }^{108}$ & $\begin{array}{l}\text { Mission, structure, process, revenues, legalities, and } \\
\text { technology }\end{array}$ & 6 & No & No \\
\hline Rayport and Jaworski ${ }^{109}$ & $\begin{array}{l}\text { Value cluster, market space offering, resource system, } \\
\text { and financial model }\end{array}$ & 4 & No & No \\
\hline Bertz $^{110}$ & Resources, sales, profits, and capital & 4 & No & No \\
\hline Hedman and Kalling'II & $\begin{array}{l}\text { Value network, resources, capabilities, revenue } \\
\text { and pricing, competitors, output, management }\end{array}$ & 7 & Some & No \\
\hline Chesbrough ${ }^{1 / 2}$ & $\begin{array}{l}\text { Customer, value network, capabilities, revenue } \\
\text { and pricing, cost, strategy }\end{array}$ & 6 & Some & No \\
\hline Rappa ${ }^{1 / 3}$ & $\begin{array}{l}\text { Types: brokerage, advertising, infomediary, merchant, } \\
\text { manufacturer (direct), affiliate, community, subscription, utility }\end{array}$ & 9 & Some & No \\
\hline Stanoevska-Slabeva and Hoyer ${ }^{1 / 4}$ & $\begin{array}{l}\text { Features of specific product, features of specific medium, } \\
\text { customers, value chain, financial flow, goods and services, } \\
\text { societal environment }\end{array}$ & 7 & No & No \\
\hline Osterwalder and Pignuer ${ }^{1 / 5}$ & $\begin{array}{l}\text { Customer segments, value propositions, channels, customer } \\
\text { relationships, revenue streams, key resources, key activities, } \\
\text { key partnerships, cost structures }\end{array}$ & 9 & Some & No \\
\hline Al-Debei and Avison ${ }^{116}$ & $\begin{array}{l}\text { Value proposition, value architecture, value finance, value } \\
\text { network (integrated approach) }\end{array}$ & 4 & Yes & No \\
\hline
\end{tabular}






Figure I Interactions between the components of the VISOR Model.

Abbreviation: NDI, Networked Digital Industry.

- What do our customers find valuable? (Is our product of better quality or lower cost? Does it match their needs better? Does it reach unserved customers or regions?)

From the VISOR perspective, value creation can be defined by the descriptors listed in Table 2.

\section{Interface}

Defined as the interaction between the customer and the service platform, the interface includes both hardware and software, and provides the bridge between the service platform and customer experience: it provides the "physical" link between the experiential or qualitative nature that the value proposition of the product or service provides and the physical infrastructure that delivers it. The proliferation of smart phones, and their operating systems, the Internet and social media, and PC tablets offer yet new interfaces for customers to access digital products and services. These new interfaces offer the possibility of reinventing business models for traditional products and services, as well as new business models for other new product offerings.

The interface addresses the following questions:
- Does the availability and affordability of new interfaces enhance the firm's traditional value proposition? (example: social networking tools allow music customers to discover new and better music through their friends; social presence is enabled by mobility and allows awareness of location and time)

- Can new interfaces help deliver a more "precise" value to customers?

- Are there any limitations of new interfaces that would diminish a customer's value proposition of a current product or service (example: how satisfying is TV on a tiny mobile device?)

- Can multiple interfaces be used simultaneously without technical challenges?

From a VISOR perspective, the Interface can be described by the descriptors listed in Table 3 .

\section{Service platforms}

The Service Platform includes the IT infrastructure that enables, shapes, and supports the business processes and organizational relationships that are necessary to deliver the

Table 2 Descriptors of the value proposition

\begin{tabular}{lll}
\hline Descriptor & Explanation & Method of assessment \\
\hline Compelling & How well does a product or service perfectly match & Probability of or actual consumption \\
Cohort & The maximum customer base in a particular market segment, & Niche or market size \\
& who view the product or service as addressing or providing a need & The number of other existing products or \\
Complementarity & The levels at which a product or service that a customer & services that are consumed interdependently \\
Cocreatibility & uses is accentuated by this new product or service & The different number of configurations that \\
& The extent to which this new digital product or service & customers can create \\
\hline
\end{tabular}

Note: Adapted from Business Modelling in the Dynamic Digital Space: An Ecosystem Approach, 2013, pg 3I, El Sawy O, Pereira F. (OThe Author(s) 20I3. With permission of Springer. ${ }^{8}$ 
Table 3 Descriptors of the interface

\begin{tabular}{|c|c|c|}
\hline Descriptor & Explanation & Method of assessment \\
\hline Functionality & $\begin{array}{l}\text { Ease of use of the interface as well as range and types } \\
\text { of interactions it supports }\end{array}$ & $\begin{array}{l}\text { Multiplicity of access to different service platforms } \\
\text { and support of tasks }\end{array}$ \\
\hline Form factor & The aesthetical properties & Customer perception \\
\hline Fluidity & $\begin{array}{l}\text { Level of intimacy, flexibility control, and personalization } \\
\text { that customers experience }\end{array}$ & Ease and level of customization \\
\hline Forgiveness & $\begin{array}{l}\text { The extent to which the interface can undo any } \\
\text { user error automatically }\end{array}$ & Adaptiveness and error correction and capabilities \\
\hline
\end{tabular}

Note: Adapted from Business Modelling in the Dynamic Digital Space: An Ecosystem Approach, 2013, pg 31, El Sawy O, Pereira F. (OThe Author(s) 20I3. With permission of Springer. ${ }^{8}$

products and services, as well as to possibly to augment the value proposition. Because services in the networked digital industry depend on technology infrastructures, any business model in the networked digital industry business must include IT platforms and ecosystems.

Since IT platforms are constantly evolving and potentially creating different competitive advantages, deciding which platform a firm should choose, or whether and how the firm can work across platforms, is a strategic decision of great importance. In deciding which IT platform to select, a firm must address the following:

- Which platform(s) provide the best medium for it to deliver its value proposition to its targeted customer base effectively and efficiently, and which matches its revenue model?

- Should it assume the dominance of one platform in the industry, or should it invest in multiple platforms to hedge the risks or should it develop a proprietary IT platform?

- If it is using multiple platforms, can it exploit the unique features of each platform and their concomitant customers' segments, by adapting its product or services offering to take advantage of it?

The concept of service platforms is elaborated through the descriptors listed in Table 4.

\section{Organizing model}

The digital ecosystem differs from traditional value chains, and is often characterized by high turbulence and where major players, very often, are simultaneously competing and cooperating. Thus, the selection and structure of partnerships are likely to change with new business ventures, unlike in traditional industries, like automotive manufacturing, which are characterized by more stable partnerships. Thus, the organizing model is an important strategic component of any business model framework as it defines and governs how a firm organizes and structures its internal core processes, external value chains, and partnership arrangements to effectively and efficiently deliver its products or services. In this new digital ecosystem, firms can partner with complementors, competitors, customers, and even the community.

In a business model, the organizing model seeks to address the following:

- What are the ancillary services that are needed to support delivery of the firms' value proposition (eg, delivery of mobile TV services requires content producers, device engineers, and network service providers)?

- How do firms identify the other best firms they should partner with, given their value proposition, identify customers' segments, select IT platforms, the necessary interfaces, and developed revenue models?

- Who are the firms' competitors if excluded from their organizing structure? How will decision-making authority be shared or controlled in this partnership venture?

- Will firms be dependent more on their partners, or would it be the reverse, or would it be a more symbiotic relationship?

Table 4 Descriptors of the service platform

\begin{tabular}{lll}
\hline Descriptor & Explanation & Method of assessment \\
\hline Architecture & $\begin{array}{l}\text { The topology of the hardware and software } \\
\text { that enables the service } \\
\text { Does the platform support different operating systems? }\end{array}$ & $\begin{array}{l}\text { Closed/proprietary or open standards } \\
\text { Agnosticity }\end{array}$ \\
Acquisition & $\begin{array}{l}\text { Highlights the issue of whether to piggyback } \\
\text { on existing technology infrastructures or to build } \\
\text { proprietary networks }\end{array}$ & $\begin{array}{l}\text { Based on type of technology selected or } \\
\text { the need for external APIs } \\
\text { Capabilities of the existing platforms and } \\
\text { their ability to deliver product or services }\end{array}$ \\
Access & $\begin{array}{l}\text { Which community or customer-base will have } \\
\text { access to these services or products }\end{array}$ & Ranges on a continuum, from completely \\
\end{tabular}

Note: Adapted from Business Modelling in the Dynamic Digital Space: An Ecosystem Approach, 2013, pg 31, El Sawy O, Pereira F. OThe Author(s) 2013. With permission of Springer. ${ }^{8}$

Abbreviation: API, application program interface. 
Table 5 Descriptors of the organizing model

\begin{tabular}{lll}
\hline Descriptor & Explanation & Method of assessment \\
\hline Processes & $\begin{array}{l}\text { How will the core business processes be structured } \\
\text { or designed to support the delivery of the digital } \\
\text { product or service? }\end{array}$ & $\begin{array}{l}\text { Performance matrix and scorecard for key } \\
\text { business processes, including product innovation, } \\
\text { customer support systems, order management } \\
\text { systems, inventory systems, etc } \\
\text { Partnerships }\end{array}$ \\
$\begin{array}{l}\text { Quality of business relationships formed with go-to- } \\
\text { market partners }\end{array}$ & $\begin{array}{l}\text { Assess terms of exclusivity, formality, and } \\
\text { expected durability of relationships of the partners }\end{array}$ \\
Pooling & $\begin{array}{l}\text { Pooling the capabilities or using the complementary } \\
\text { effectively deliver the customer value }\end{array}$ & $\begin{array}{l}\text { The levels of complementarity and synergy of the } \\
\text { various resources available (talent, technology, etc) }\end{array}$ \\
Project management & $\begin{array}{l}\text { Resources coordination among the different } \\
\text { partners to launch the product or service, and its } \\
\text { subsequent provision }\end{array}$ & $\begin{array}{l}\text { Likelihood the venture will be successful given } \\
\text { complexity of relationships and tasks required }\end{array}$ \\
\hline
\end{tabular}

Note: Adapted from Business Modelling in the Dynamic Digital Space: An Ecosystem Approach, 2013, pg 33, El Sawy O, Pereira F. @The Author(s) 2013. With permission of Springer. ${ }^{8}$

In the VISOR Business Model, the Organizing Model is described using the descriptors listed in Table 5.

\section{Revenue model}

As defined above, successful business models require that the value proposition the firm offers, as captured by its revenue, must exceed the costs incurred from the production and delivery of the product or service and the investments in IT platforms so that it remains attractive for all partners. The VISOR framework suggests, as illustrated in Figure 1, that any deficiencies with the Interface, Service Delivery or Organizing Model components of the model could potentially be offset proportionally by a high Value Proposition to the target consumer segment together with a concomitant Revenue/Cost model.

Some key issues that the revenue model has to address and incorporate include:

- What is the appropriate pricing structure?

- How will revenue be allocated among partners?

- How will the point when the investment becomes profitable (revenues exceed costs) be determined?

In the VISOR framework, the revenue model is described by the descriptors listed in Table 6 .

\section{Applying the VISOR Business Model Value proposition}

In the past, research has shown that telemedicine has been most useful when direct contact between patient and clinician, or transportation of patients to clinician, has been hindered by geography, distance, terrain, climate, or other physical barriers. ${ }^{24}$ Thus, the unprecedented accessibility that patients have to mobile phones today, and the ubiquity of the cellular network, provide the potential to greatly alleviate the cost pressures in health-care management.

Specifically, the increasing cost pressures on the US health system could be alleviated through savings from the reduced costs of serving patients attained through 1) better chronic disease management; 2) reduction in both travel and time for patients and doctors; 3 ) and from the provision of better health care, generating cost reductions from increased monitoring, and early diagnosis of chronic diseases, such as hypertension, ${ }^{25}$ diabetes mellitus, COPD, and heart disease. Specifically, COPD remains a leading cause of hospitalization for the older people in the US; some $65 \%$ of the annual 638,000 or so hospital discharges were patients 65 years and older. ${ }^{26}$ Also, some $20 \%$ of Americans will develop congestive heart failure (CHF). Similarly, about $85 \%$ of African

Table 6 Descriptors of the revenue model

\begin{tabular}{|c|c|c|}
\hline Descriptor & Explanation & Method of assessment \\
\hline Pricing & Structure of pricing mechanism & $\begin{array}{l}\text { Selection of appropriate pricing method, eg, pay-as- } \\
\text { you-go, subscription, advertising supported, the } \\
\text { "buffet model", micropayments, etc }\end{array}$ \\
\hline Partner revenue sharing & $\begin{array}{l}\text { How revenue is shared among partners who } \\
\text { are bringing the joint offering to market }\end{array}$ & Distribution proration among partners \\
\hline Product cost structure & $\begin{array}{l}\text { Direct and indirect cost of key resources } \\
\text { required }\end{array}$ & Product margins and cost assessment \\
\hline Potential volume & $\begin{array}{l}\text { How much demand is expected in target } \\
\text { market segment }\end{array}$ & $\begin{array}{l}\text { Expected number of "units" sold in specified } \\
\text { time period }\end{array}$ \\
\hline
\end{tabular}

Note: Adapted from Business Modelling in the Dynamic Digital Space: An Ecosystem Approach, 20I3, pg 33, El Sawy O, Pereira F. @The Author(s) 20I3. With permission of Springer. ${ }^{8}$ 
Americans and 74\% of Hispanics aged 65 years and older suffer from hypertension, which costs the US society about $\$ 47.5$ billion in annual direct medical expenses. ${ }^{27}$ But in spite of advances in medical care and pharmacological therapy, outcomes related to heart failure still remain relatively poor. ${ }^{28}$ Given a 6-month readmission rate of some 44\%, appropriate disease management for $\mathrm{CHF}$ patients is critical, and for people over 65 years in the US, it remains one of the leading causes of hospital admission. Not surprisingly, the treatment of high-risk heart failure patients accounts for an estimated $1 \%-2 \%$ of the total heart care budget both in Europe and the US. ${ }^{24}$ Studies have shown that with telemonitoring, survival rates have improved, and there has been about a $26 \%$ reduction in number of days of in-hospital stays for patients. ${ }^{28-30}$ This is a viable technology, as shown by the large number of internet-based wireless telemedicine applications, such as portable health monitoring devices and mHealth units, which seamless connect wirelessly with a central service center. ${ }^{31}$ Similarly, in-home monitoring of patients with $\mathrm{CHF}$ has shown to lead to a $20 \%$ reduction in hospitalization, and a $21 \%$ reduction in mortality. ${ }^{32}$ While telehealth may not be able to directly treat patients with these chronic diseases, in-home monitoring reduces the incidences of hospitalization, which reduces health-care costs, and reduces the pressure on the need to increase the number of hospital beds. In the longer run, telehealth-enabled preventive care could potentially reduce the number of people with chronic diseases.

In a comprehensive and landmark retrospective analysis of 2009-2012 Veterans Health Administration (VHA) administrative data, Darkins et al $^{33}$ analyzed 4,999 care coordination home telehealth (CCHT)-noninstitutional care (NIC) patients compared with usual (non-CCHT) care in a matched cohort group (MCG) of 183,872 veterans. Both cohorts comprised patients with complex chronic conditions with statistically similar baseline (pre-CCHT enrollment) health-care costs, when adjusted for age, sex, chronic disease, emergency room visits, hospital admissions, hospital lengths of stay, and pharmacy costs. Subsequent analyses after 12 months of CCHT-NIC enrollment showed that mean annual healthcare costs for CCHT-NIC patients fell 4\%, from \$21,071 to $\$ 20,206$, whereas the corresponding costs for MCG patients increased $48 \%$, from $\$ 20,937$ to $\$ 31,055$. The summary of the results is shown in Table 7.

In another study, telehealth monitoring of patient vital signs reduced health service utilization for individuals with COPD and resulted in significant annual cost savings of \$2,931 per person over the control group, as well as improvements in participants' self-management behaviors and control over their condition. ${ }^{34}$ Other studies also show significant differences between hospital care and in-home care for other medical conditions such as low birth weight, chemotherapy for children with cancer, and ventilator-dependent adults. ${ }^{35-38}$ Thus, the value proposition of telehealth in the US is extremely high.

However, most of these eHealth applications have been deployed on a limited scope and scale, and there is no widespread deployment of this mobile technology, and telehealth, as such, remains very much in the "early adopter stage". 39 Furthermore, most companies are still in the testing stages of telehealth systems and their related technologies, and only a few long-term programs have been implemented. Much of the current impetus for mobile telehealth is being generated by technology companies that see the future revenue potential. ${ }^{31}$

Most of the current mobile telehealth technologies and applications are focused on homecare, where patient-doctor relationships, historically, have been characterized by long-term and time-consuming communications and repeated clinic visits. Through real-time health monitoring, as well as the provision of immediate attention to acute care patients (eg, emergency arrivals) and patients in rural areas, telehealth could alleviate the health care expertise resource problem, by providing both an efficient and effective way to care for existing patients.

Another key area where telehealth could reduce costs and increase efficiency in the health system is in follow-up care, ${ }^{40-42}$ particularly for medical conditions where the visual

Table 7 Comparison of demographic and resource utilization data between MCG and CCHT-NIC

\begin{tabular}{|c|c|c|c|c|}
\hline & \multicolumn{2}{|l|}{2009} & \multicolumn{2}{|l|}{2012} \\
\hline & $\begin{array}{l}\text { MCG } \\
\text { ( } n=183,872 \text { patients) }\end{array}$ & $\begin{array}{l}\text { CCHT-NIC } \\
\text { ( } n=4,999 \text { patients) }\end{array}$ & $\begin{array}{l}\text { MCG } \\
\text { ( } n=\mid 83,872 \text { patients) }\end{array}$ & $\begin{array}{l}\text { CCHT-NIC } \\
\text { ( } n=4,999 \text { patients) }\end{array}$ \\
\hline Cost, US\$ (mean) & $\$ 20,937$ & $\$ 21,071$ & $\$ 31,055$ & $\$ 20,206$ \\
\hline Emergency room visits (mean annual number) & 0.65 & 0.84 & 0.63 & 0.58 \\
\hline Hospital admissions (mean annual days) & 0.56 & 0.72 & 0.76 & 0.49 \\
\hline Pharmacy costs (mean annual costs) & $\$ 2,132$ & $\$ 2,117$ & $\$ 2,458$ & $\$ 2,587$ \\
\hline Clinic visits (mean annual number) & 45.7 & 33.5 & 64.42 & 50.53 \\
\hline Annual Medicare cost (mean cost) & $\$ 4,176$ & $\$ 2,515$ & $\$ 6,504$ & $\$ 3,593$ \\
\hline
\end{tabular}

Abbreviations: MCG, matched cohort group; CCHT-NIC, Care Coordination Home Telehealth - Non-Institutional Care Group. 
aspects, such as photographs, are critical to evaluate the medical status of the patient, such as in surgery aftercare and chemotherapy: pilot tests have been conducted for mobile phone-based follow-up care for patients in these areas. Similarly, dermatology, where images and photographs are used extensively in diagnosis and treatment, is well positioned to exploit mobile telehealth. ${ }^{43}$

The use of mobile telehealth in rural health care also holds promise. While the doctor-patient ratio may be relatively low in these areas compared to urban areas, most patients in these areas have cell phones and are within the range of cell phone towers. ${ }^{31,44-46}$ Applications that increase or support doctor-patient communications, such as text messaging systems (SMS) that provide appointment reminders, have been the first types of applications downloaded to the mobile phone to support in telehealth. Quantitative statistical studies show that these applications have had some success in countries such as New Zealand and Philippines. ${ }^{46,47}$ mHealth and eHealth could also provide the platform for preventive medicine, and it is estimated that some $\$ 500$ billion could be saved in the US by addressing obesity, smoking, and other modifiable risk factors.

Other studies support the conclusion that most patients, even older patients, are generally satisfied with telehome health services and telehealth, particularly in the treatment of COPD, CHF, and chronic wound care, with patient satisfaction levels increasing with increased levels of telehealth care intervention. ${ }^{27,48-50}$ Similarly, conclusions, as shown in Figure 2, can be drawn from a random survey conducted in North America involving over 5,000 respondents, which shows high consumer interest in using both wireless technologies as well as the terrestrial internet to better manage their health-care needs. ${ }^{51}$
While "early adopters", ie, those generally defined to have smartphones and tablets, have fully embraced the use of the Internet to improve their individual health-care management, as illustrated in Figure 3, a large and increasing percentage of the "majority group" are also embracing the Internet to help manage their own or, as a health caregiver, someone else's health. These findings are similarly reflected in other studies, such as the Pew Internet and American Life Project. ${ }^{52}$

Table 8 suggests some of the policies or strategies that could be used to further enhance the value proposition of telehealth, particularly for end-users. Specifically, using the cell phone or other consumer mobile devices, such as tablets and even game consoles as the access device, and developing appropriate applications for these devices will increase adoption. Furthermore, using open versus proprietary platforms will also increase innovation for more telehealth applications.

\section{Interface}

Defined generally in terms of ease of use, simplicity, and convenience, the user interface experience is important for adoption of any goods or services, but is particularly important for technology-enabled services, such as mHealth. Since most health-care professionals currently routinely use handheld and wireless devices, training in the use of this technology is not expected to be a major issue. Furthermore, given the popularity and prevalence of use of the personal digital assistants among physicians, both as a communication device and as a means to access prescription and other information from medical reference databases, it is expected that most caregivers will generally to use the PDA for mHealth. Given the ubiquity of cell phones among patients, it is the obvious platform for application developers who have created, among other



Figure 2 Respondents' views on usefulness of various digital home health services. 



Figure 3 Percentage of respondents' agreeing with the following statements on gathering health information online.

applications, insulin and heart rate monitoring functions for cell phones, and are beginning to develop applications that support telemonitoring and remote patient education in the home. Small-scale clinical trials repeatedly find that "extreme" simplicity is needed for home health applications since most of the patients who have been released from the hospital and expected to use these applications are generally older and may have limited experience with computers ${ }^{48}$ Furthermore, from a user interface perspective, these applications must account for potential physical limitation of patients due to medical conditions such as rheumatoid arthritis, vision, and other problems..$^{53}$ This is a critical requirement, and devices and their interfaces must be designed to adapt to a patient's limited capabilities, including dementia, or lack of stamina, or disabilities. This is reflected in Figure 4, which reiterates that ease of use and familiarity of the device interface remain key

Table 8 Recommended "settings" for the value proposition of the VISOR Model

\begin{tabular}{ll}
\hline Descriptor & Comments \\
\hline Compelling & $\begin{array}{l}\text { The viability of eHealth is demonstrated by } \\
\text { the large and growing consumer interest } \\
\text { in eHealth services and applications, which } \\
\text { may provide a solution to the growing } \\
\text { health costs for many consumers } \\
\text { Studies show that all demographic groups } \\
\text { value e-health and their related applications. } \\
\text { Applications, such as home-monitoring, } \\
\text { represent a large potential revenue stream } \\
\text { The use of smart phones as the access } \\
\text { platform provides a familiar means for } \\
\text { access for various mobile health applications } \\
\text { While regulation will remain important, } \\
\text { open platforms provide the potential for } \\
\text { greater innovation of new applications from } \\
\text { developers as well as end-users }\end{array}$ \\
\hline
\end{tabular}

end-user requirements. ${ }^{51} \mathrm{~A}$ potential solution to this problem of limiting and changeable usage abilities may lie in intuitive interfaces that can learn and adapt to an individual's capability. Studies suggest that even nontechnical individuals are interested in learning how to use mobile and wireless services if they provide them more independence. ${ }^{54}$

Perhaps, the most important aspect to encourage rapid adoption of telehealth services and applications to allow the end-user interface to easily adapt to users' differences in technical competence and physical capabilities. Some of these requirements are described in Table 9.

\section{Service platform}

As discussed in the introductory sections, the fact that telemedicine has existed since the $1920 \mathrm{~s}$, as well as the potential economic benefits that telemedicine provides, notwithstanding, deployment and adoption of this technology remain low, principally because of several technical, structural, and social constraints. Many of these constraints, such as low compatibility with how medicine is practiced, the complexity of the telemedicine equipment interfaces, and at times, use of the equipment itself, the prevalence of multiple technical standards..$^{55,56}$ physicians' unfamiliarity with the technology, and ineffective training and change management, ${ }^{57}$ still persist today. ${ }^{54}$ Furthermore, with the availability of new wireless technologies and standards for mobile telehealth, such as GSM, GPRS, 3G, Bluetooth, WiFi, and Zigbee, these interoperability issues may have been exacerbated..$^{58}$ Also, given the recent data breaches in the health sector, network security has become a primary concern. Thus, a high level of security, characterized in part by encryption, authentication, and controlled access, to protect health-care data is necessary and critical for mobile telehealth. ${ }^{54}$ Because 


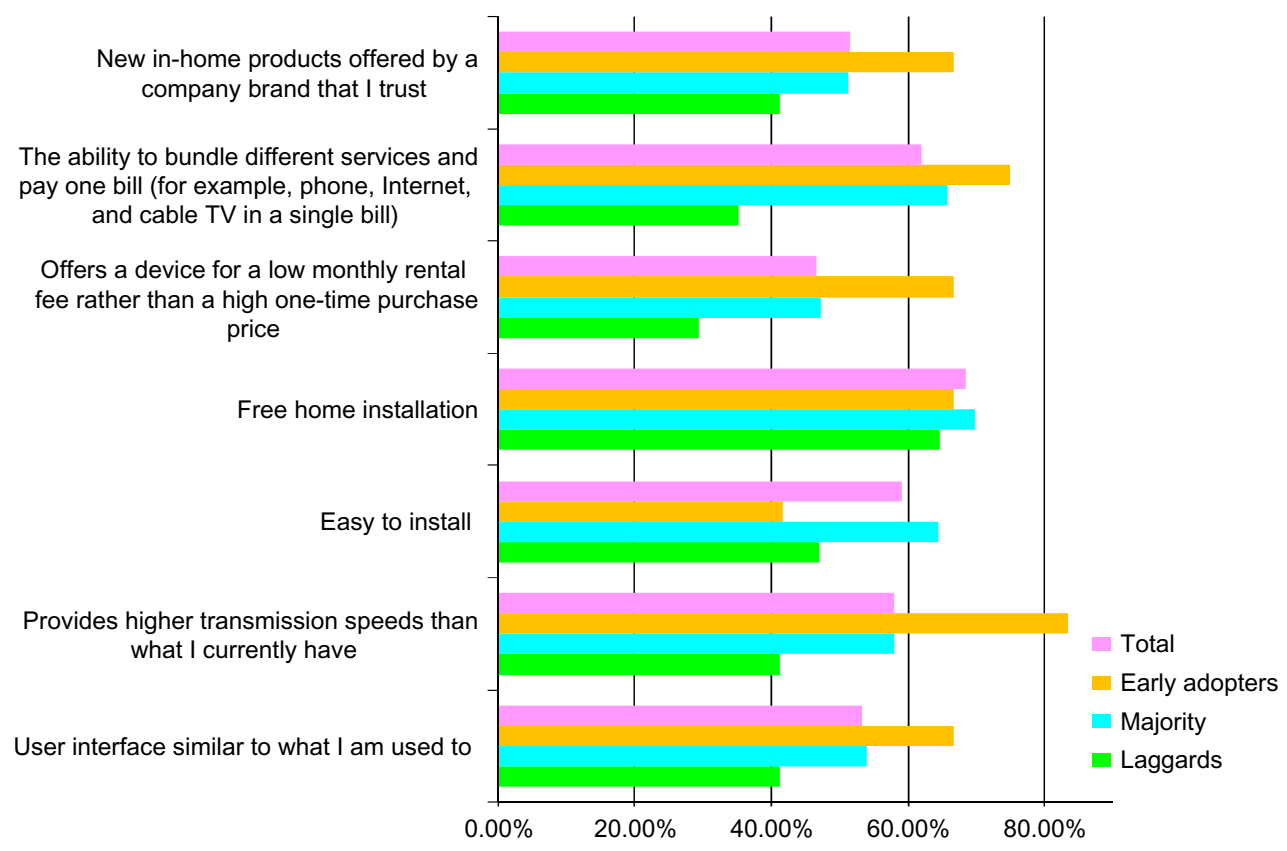

Figure 4 Percentage of respondents' agreeing with the following statements on requirements for user interface devices.

of the current state of the network, most of the wireless telehealth applications used today are considered "low risk" and involve only text messaging, simple patient data, and checking prescriptions. ${ }^{59}$

Deploying a multinetwork approach may provide a solution to current wireless network challenges. Specifically, Varshney ${ }^{54}$ asserts that the current cellular networks used in conjunction with wireless local area networks (LANs) and satellites to help provide coverage, redundancy, and reliability could form the basis of a reliable and usable wireless infrastructure that affords easy access and supports prioritized communications. Additionally, a potentially higher degree of service quality and scalability could be achieved by switching between multiple networks, which would help overcome the limitations in current wireless networks. But,

Table 9 Recommended "settings" for Interface in the VISOR Model

\begin{tabular}{ll}
\hline Descriptor & Comments \\
\hline Functionality & $\begin{array}{l}\text { Given patients' differing physical capabilities, devices } \\
\text { and applications must be versatile enough to } \\
\text { accommodate } \\
\text { May not be as crucial as some of the other qualities, } \\
\text { Form factor }\end{array}$ \\
Fluidity & $\begin{array}{l}\text { For ease of use, single-use as opposed to } \\
\text { multifunction devices may be preferred for medical } \\
\text { applications and services } \\
\text { Forgiveness }\end{array}$ \\
& $\begin{array}{l}\text { Given potential differences in patients' experiences } \\
\text { with technology, automated correction of end-user } \\
\text { "error” is crucial for eHealth applications }\end{array}$ \\
\hline
\end{tabular}

technical interoperability between telehealth devices remains a significant obstacle. Thus, while the use of mobile phones is ubiquitous, the rate of adoption of mobile telehealth applications and services, using the cellular platform, will depend on how successful telecommunication network providers will be able to integrate their platforms with hospital and other health-related IT systems as well as other medical devices and interfaces. ${ }^{60}$ Specifically, in mobile telehealth, in order to preserve the integrity of data and appropriate patient care, it is extremely important to seamlessly integrate new telehealth data into existing hospital record systems.

One of the most significant challenges related to adoption of telehealth is not technology-based but "people-based" issues and involves its integration with current workflows. In the case of a mobile telehealth system, this would require the integration of eHealth applications with traditional workflows (or replacement of some activities). While patients have found the use of mobile phones in health care to be relatively easy, ${ }^{48}$ health-care providers on the other hand have been confronted with scalability issues, the need for meticulous planning, strategic phasing, and ongoing assessments in deployment of the system. These issues are likely to remain immense challenges.

For social and legal requirements, telehealth applications must be ubiquitously available to all, regardless of geographical locations. Thus, providing these services through national telecommunication service providers' networks would afford both the most cost-effective way to deploy these services, as well achieve universal access. Table 10 outlines some of the 
Table I0 Recommended "settings" for Service Platform in the VISOR Model

\begin{tabular}{ll}
\hline Descriptor & Comments \\
\hline Architecture & $\begin{array}{l}\text { Greater and rapid innovation of new applications } \\
\text { and services may be spurred by adoption of } \\
\text { nonproprietary/open systems } \\
\text { Interoperability of access devices is crucial } \\
\text { for rapid adoption and to ensure that medical } \\
\text { applications will not fail on different devices }\end{array}$ \\
Mcquisition & $\begin{array}{l}\text { Most cost-effective approach, and which would } \\
\text { provide the greatest value for all stakeholders, }\end{array}$ \\
& would be to run applications on the current \\
& NGN platforms of network service providers \\
Access & For social and political reasons, must be available \\
& to all
\end{tabular}

Abbreviation: NGN, next-generation network.

recommendations to resolve the current technical challenges associated with deployment of telehealth services.

\section{Organizing model}

In many countries, the medical health ecosystem system is very complex and structured, none more so perhaps as in the US. Specifically, in the US, at least 12 Federal and State Agencies regulate the health industry, including the Department of Health and Human Services, the Drug Enforcement Agency, and the Food and Drug Administration at the Federal level. ${ }^{55}$ However, in the case of mobile telehealth, since health applications will use the cellular networks, oversight would also have to be provided by the Federal Communications Commission. From a medical health ecosystem perspective, with the exception of perhaps the American College of Radiology, there has been ambivalent support for telemedicine from the leading US medical institutions, particularly the American Medical Association, and most medical schools and college, as well as the majority of doctors and hub hospitals. ${ }^{61}$ Several key societal impediments to the use of telemedicine can account for this ambivalence, most significantly, the tension between state laws on medical licensure telemedicine ${ }^{62}$ which, under the present individual state licensure system, requires physicians to be medically certified and licensed in each state in which they teleconsult with their patients. This thus practically limits telemedicine to the State borders and as such curbs the potential geographic benefits that mobile telehealth solutions can provide. ${ }^{63}$ Furthermore, there remains significant ambiguity on whether telemedicine services are covered under malpractice insurance policies. ${ }^{64}$ These legal malpractice issues and challenges are compounded when these services extend beyond individual state borders. ${ }^{65}$
Furthermore, as already discussed, technical security protocols in the networks are needed to ensure the confidentiality of patient medical information and record for mobile telehealth, ${ }^{66}$ perhaps more so than for other types of personal information. $3 \mathrm{G}$ networks however, remain vulnerable to malware attacks. Medical history and records, if used inappropriately, can be severely detrimental against the patient. The challenge remains to include security and privacy protocols into mobile telehealth applications since mobile networks may not be $100 \%$ secure.

Perhaps, one of the most critical factors for the success of telehealth is the necessity of identifying all the stakeholders in the telehealth system, and establishing an alliance structure.$^{67}$ Traditionally, the health ecosystem has been narrowly defined to include only the health provider, the insurance company, and the patient. However, since the benefits of telemedicine accrue to many other entities beyond these traditional stakeholders, these new parties have to be included. At the very least, these would include the national telecommunication service providers, equipment manufacturers, software service providers, major corporations, and State agencies.

As Table 11 suggests, the role of a keystone player will be pivotal for the successful deployment of telehealth services on a national level. The participation of a national common communication carrier, for example AT\&T in the US, could potentially provide the leverage to bring the different stakeholders together to resolve some of the obstacles discussed, above, including perhaps advocating for the establishment of a Federal Tele-Health Commission. Such a Federal Commission in the US would significantly reduce any bureaucratic and legal frictions created by multiple agency supervision.

Table I I Recommended "settings" for Organizing Model in the VISOR Model

\begin{tabular}{ll}
\hline Descriptor & Comments \\
\hline Processes & $\begin{array}{l}\text { The active support of network service providers is } \\
\text { crucial to resolve the technical complexity related } \\
\text { to the delivery of e-health services, participation. } \\
\text { US network service providers have just begun } \\
\text { exploring eHealth as a service. Network service } \\
\text { providers are in a unique position to help set and/or } \\
\text { establish standards and protocols for eHealth } \\
\text { Formal partnerships are a prerequisite with a "key- } \\
\text { stone" player taking the lead } \\
\text { Cost effective and efficient delivery of eHealth } \\
\text { Pooling }\end{array} \quad \begin{array}{l}\text { medications would require the stakeholders in the } \\
\text { Success crucially requires coordination of efforts } \\
\text { by the different partners and stakeholders. Will } \\
\text { the government taking the lead help accelerate the } \\
\text { management }\end{array}$ \\
\hline
\end{tabular}




\section{Revenue model}

Both in the US and Europe, the deployment costs of a mobile telehealth or telemedicine infrastructure, and the reimbursement of services provided over this network, remain two major impediments to the rapid deployment of telemedicine applications. ${ }^{68,69}$ Currently, most of the technology costs and the consultations carried out through telemedicine are not reimbursed. ${ }^{70}$ Most of the telemedicine initiatives are being run by organizations which are usually financed by demonstration grants, like the military, research centers, or state-owned hospitals, and, as such, are not too concerned with the revenue model or reimbursements. Although studies have shown the viability and profitability of telemedicine, through outpatient clinics associated with hospitals in nonrural areas, only a small number of these for-profit medical centers are involved in telemedicine and many of these, like the Mayo Clinic, are deploying closed telemedicine systems. ${ }^{71,72}$ Furthermore, out of fear that the telemedicine equipment will be fast outdated, medical organizations are reluctant to purchase such equipment. ${ }^{58,73}$

While the many studies conducted show the potential cost savings due to telehealth and remote monitoring, both in the US and in other countries, the fact that most of these studies still involve small sample sizes with diverse types and doses for telehomecare intervention and for select chronic illnesses, such as heart failure and COPD presents a challenge to the revenue model. ${ }^{27,74-78} \mathrm{Also}$, other studies argue that the outcome of telemedicine in these areas is not conclusive due to definition and measurement issues. ${ }^{79,80}$ A 1992 study by the Arthur D. Little Consulting Company which estimated then, that telemedicine would have resulted in savings of \$36 billion annually, was perhaps the first, and one of the few, comprehensive studies that tried to estimate the potential savings from telemedicine. ${ }^{81}$ However, a more recent study estimates increases in efficiency in health care from wireless telecom solutions alone will increase from almost $\$ 4.5$ billion in 2005 to $\$ 29.2$ billion in $2015 .^{82}$

The potential economic returns and benefits to employers that telehealth applications can provide is another area of economic analysis that is lacking. For example, employees who are also primary health caregivers may enjoy "ease of mind" as they are able to monitor their loved ones, and thus companies may not experience any loss of productivity. There are no studies in this respect that analyze the productivity effects. Similarly, there is a dearth of comprehensive studies that enumerate the research benefits accruing to continuous access to electronic patient health data, and real-time analyses of possible effects of medication and other treatment. Such studies could help both in refinement or development of new medical procedures and medications.$^{83}$ Fundamentally, no comprehensive studies have been done to estimate the economic benefits of telehealth to society in general, and the cost reductions to national health care spending, both private and public attained through telehealh application, specifically, several reports have reemphasized the need for such studies, recently. ${ }^{84,85}$ Furthermore, two aspects that currently are not included in these analyses are 1) the economic savings from early detection and monitoring of infectious diseases: It has been estimated that Hong Kong's gross domestic product contracted by $1.8 \%$ in 2003 due to the severe acute respiratory syndrome outbreak ${ }^{86}$ and 2) productivity increases in businesses from wellness programs. As discussed in the Revenue model section, most studies deal with only chronic diseases, and involve small numbers of patients. Since the potential economic benefits of telehealth accrue to employers and the government, they are relevant stakeholders that have to be included.

The cost saving estimates from telemedicine today are not very different from the estimates made in 1992, attesting to the lack of progress in trying to quantify the economic benefits of telemedicine in the US over the past 20 years or so.$^{87}$ However, in this respect, some work has been done in areas like electronic records by the largest of the integrated medical groups (ie, the Mayo Clinic, Kaiser Permanente, and the University of Pittsburgh Medical Center among others) ${ }^{88}$ While large medical groups have been generally quick to adopt electronic record systems, smaller practices however, among other issues, have found the initial setup costs of these systems to be high and that they are tailored to larger entities. In this respect, webbased services offer promising alternatives; Internet-based

Table I 2 Recommended "settings" for "Revenue Model" in the VISOR Model

\begin{tabular}{ll}
\hline Descriptor & Comments \\
\hline Pricing & $\begin{array}{l}\text { Because all stakeholders in society will benefit } \\
\text { from a telehealth system, "subsidized pricing" } \\
\text { by government, corporations, and other private } \\
\text { stakeholders is both appropriate and required } \\
\text { to encourage ubiquitous adoption. Subscription } \\
\text { pricing for various tiers of types of services }\end{array}$ \\
would prove optimal \\
Requires equitable revenue sharing agreements \\
for all stakeholders in the ecosystem \\
shartner revenue & Costs defrayed among all stakeholders and \\
Product cost & across multiple applications and services may \\
structure & keep costs manageable \\
Potential volume & Demand for the various eHealth services \\
& across all age groups is potentially high
\end{tabular}




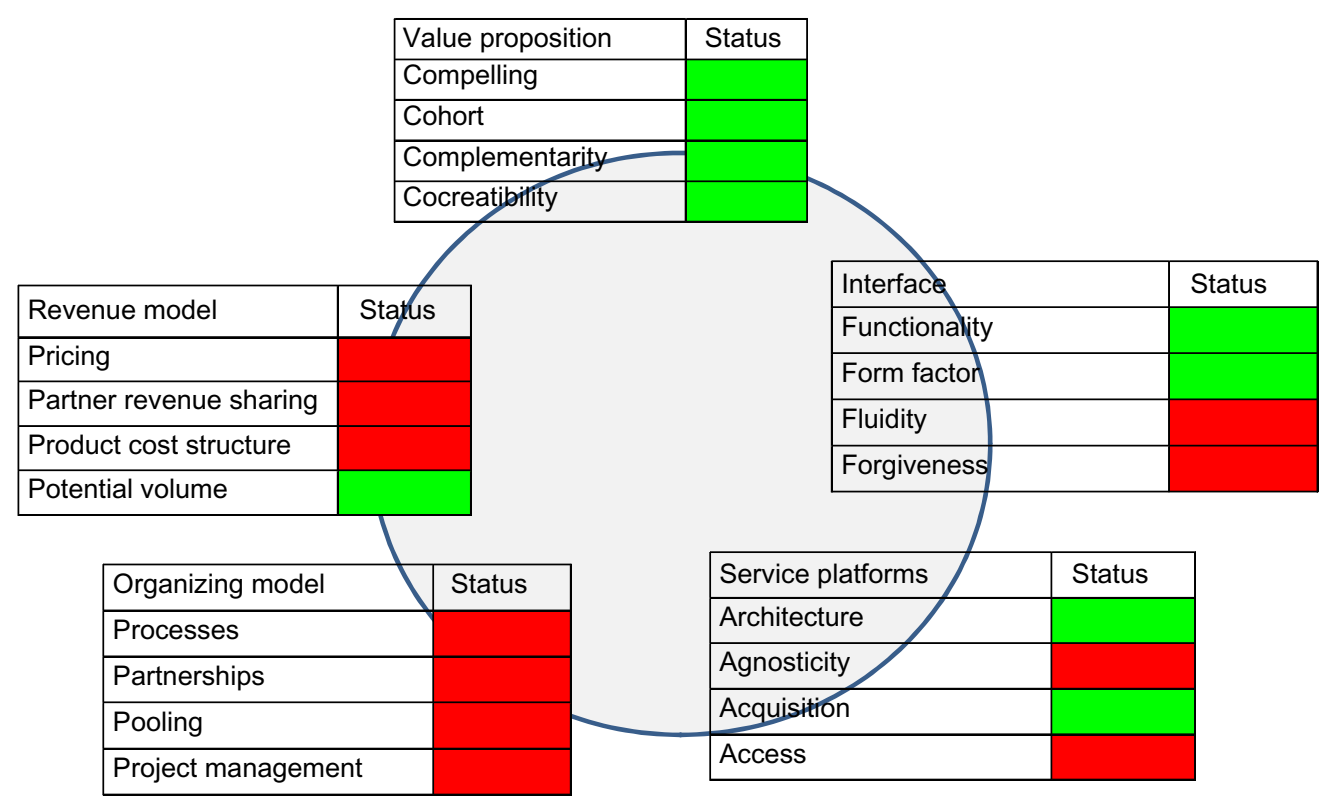

Figure 5 VISOR analyses of telehealth in the United States.

Notes: The circle denotes the interactions between the components. It also summarizes the current challenges and barriers, denoted in red, of each of the components in the VISOR Business Model while conversely, the green boxes show the factors driving the need for telehealth.

service providers are seen by many as the emerging players in health-care provision, ${ }^{89}$ such as patient access and transfer of medical records being offered by Google and Microsoft.

Although the overall cost of telehealth systems is yet to be established, it is expected that the greatest costs will accrue to human resource implementation and training, since hardware costs such as mobile phone devices are relatively inexpensive and mobile networks have already been deployed. There are expected cost savings based on the pilot tests done in certain countries.

As shown in table 12, one of the key challenges impeding widespread deployment of telehealth services involves developing an appropriate pricing plan. However, given the potentially high capital cost of deploying a national telehealth network, reasonable pricing can only be achieved if such costs are defrayed over all stakeholders on society, including the government and corporations. Thus, a comprehensive analysis of all the benefits of telehealth must be considered to justify participation by nontraditional health stakeholders in building such a network. Table 12 further discusses some of the policy recommendations that could alleviate some of the revenue challenges to the deployment of a telehealth system.

\section{Conclusion}

The analyses of telemedicine and mobile telehealth through the VISOR framework illustrate that while technology issues such as security and privacy consideration remain key factors that will determine the rate of adoption of telehealth, nontechnological challenges are equally, if not more, important. In the US health ecosystem, these include organizational, including regulatory, and revenue-model issues. Some of these issues hold true for other countries as well. The above analyses thus suggest that rapid telehealth adoption can only be achieved when, on the one hand, the service platform, (perhaps more importantly) the organizational and revenue model, and on the other the interface and to a lesser extent value proposition are all adequately addressed. Figure 5 represents a stylized VISOR framework, with the circle denoting the interactions between the components. It also summarizes the current challenges and barriers, denoted in red, of each of the components in the VISOR Business model while conversely, the green boxes show the factors driving the need for telehealth. While traditional discussions on the cost and benefits of telehealth have been focused on the health provider, insurance company, and patient, as the benefits of telehealth accrue to other potential parties, as this paper has argued, these nontraditional stakeholders have to be included. These would include the national telecommunication service providers, equipment manufacturers, software service providers, major corporations, and the State, with one of these major stakeholders, such as a national communication carrier, perhaps acting as a "keystone" player, in the business ecosystem. ${ }^{90}$ Such a keystone player could push for the establishment of a Federal Telehealth Commission that would 
streamline some of the legal and regulatory challenges, and perhaps alter the current definition of telehealth in the US to "bringing the patient to the doctor" as opposed to the reverse. Although the Obama Administration has enthusiastically supported mobile health-care initiatives as a means of increasing health care more efficiently, there is currently relatively little federal government financial support in the US to facilitate the adoption of mHealth or telemedicine. Thus, telehealth remains currently in the exploratory stage.

\section{Disclosure}

The author has no conflicts of interest to declare.

\section{References}

1. Darkin A, Ryan P, Kobb R, et al. Care Coordination/Home Telehealth: the systematic implementation of health informatics, home telehealth, and disease management to support the care of veteran patients with chronic conditions. Telemed J E Health. 2008;14(10): 1118-1126.

2. The World Bank. Health Expenditures. Available from: http://data. worldbank.org/indicator/SH.XPD.TOTL.ZS/. Accessed August 25, 2015.

3. Cabral J, Kim Y. Multimedia systems for telemedicine and their requirements. IEEE Commun Mag. 1996;34(7):20-27.

4. Teyhen D, Edinborough E, Aldag Ma, et al. Leveraging technology: creating and sustaining changes for health. Telemed J E Health. 2014; 20(9):835-848.

5. Glendinning D. Slow connection: medicare and telehealth. September 3, 2007. Available from: http://www.ama-assn.org/amednews/2007/09/03/ gvsa0903.htm. Accessed August 25, 2015.

6. Centers for Medicare and Medicaid Services. Historical Data. Available from: https://www.cms.gov/Research-Statistics-Data-and-Systems/ Statistics-Trends-and-Reports/NationalHealthExpendData/NationalHealthAccountsHistorical.html. Accessed August 25, 2015.

7. Neufeld D, Doarn C. Telemedicine spending by Medicare: a snapshot from 2012. Telemed J E Health. 2015;21(8):686-693.

8. El Sawy O, Pereira F. Business Modelling in the Dynamic Digital Space: An Ecosystem Approach. New York, NY: Springer; 2013.

9. Chen S, Cheng BS, Mehta K. A review of business models. Telemed J E Health. 2013;19(4):287-297.

10. Rogove H, McArthur D, Demaershalk B, Vespa P. Barriers to telemedicine: survey of current users in acute care units. Telemed J E Health. 2012;18(1):48-53.

11. Schafer S, Smith HJ, Linder J. The power of business models. Bus Horiz. 2005;48:199-207.

12. Casadesus-Masanell R, Ricart J. From Strategy to Business Models and Tactics. Working Paper \#10-036. Boston, MA: Harvard Business School; November 2009.

13. Hoyer V, Stanoevska-Slabeva K. Generic business model types for enterprise mashup intermediaries. Paper presented at: Proceedings of the Fifteenth Americas Conference on Information Systems, August 6-9, 2009, San Francisco, CA.

14. Linder JC, Cantrell S. Changing Business Models: Surveying the Landscape, Institute for Strategic Change. New York, NY: Accenture; 2000.

15. Morris M, Schindehutte M, Allen J. The entrepreneur's business model: towards a unified perspective. J Bus Res. 2005;58:726-735.

16. Kalantari M. Business model as an institution. Lancaster University, UK: IMP Doctoral Consortium; 2010. Available from: http://www. impgroup.org/uploads/papers/7371.pdf. Accessed August 25, 2015.

17. Baden-Fuller C, Demil B, Lecoq X, MacMillan I. Editorial: business models special issue. Long Range Plann. 2010;43(2-3):143-145.
18. Timmers P. Electronic Commerce-Strategies and Models for Businessto-Business Trading. London, UK: John Wiley \& Sons Ltd; 2000.

19. Stewart DW, Zhao Q. Internet marketing, business models and public policy. J Publ Pol. 2000;19:287-296.

20. Mayo MC, Brown GS. Building a competitive business model. Ivey Bus J. 1999;63:18-23.

21. Slywotzky AJ. Value Migration. Boston, MA: Corporate Decisions Inc.; 1996.

22. Fife E, Pereira F. Adoption of mobile data services: towards a framework for sector analysis. In: Pagani M, editor. Mobile and Wireless Systems Beyond 3G. Hershey, PA: Idea Group; 2005.

23. Mageretta J. Why business models matter. Harv Bus Rev. 2002;80(5): 86-92.

24. Larsen D, Hudnall Stamm B, Davis K, Magaletta P. Prison telemedicine and telehealth utilization in the United States. Telemed $J$ E Health. 2004;10(2);S81-S89.

25. Bin-Abbas B, Jabbari M, Al-Fares A, El-Dali A, Al-Orifi F. Effects of mobile phone short text messages on glycemic control in children with type 1 diabetes. J Telemed Telecare. 2014;20(3):153-156.

26. American Lung Association. Available from: http://www.lung.org/ assets/documents/publications/lung-disease-data/LDD_2008.pdf. Accessed August 25, 2015.

27. Czaja SJ, Lee CC, Arana N, Nair S, Sharit J. Use of telehealth systems by older adults with hypertension. J Telemed Telecare. 2014; 20(4):181-191.

28. Seibert PS, Whitmore T, Patterson C, Parker PD. Telemedicine facilitates $\mathrm{CHF}$ home health care for those with systolic dysfunction. Int JTelemed Appl. 2008;2008:235031.

29. Phillips Medical System. Ten-HMS Study Demonstrates Clinical and Financial Efficacy of Home Monitoring. Andover, MA: Phillips Medical Systems; 2003.

30. Xiang R, Li L, Liu S. Meta analysis and meta-regression of telehealth programmes for patients with chronic heart failure. Journal of Telemedicine and Telecare, 2013;19(5) 249-259.

31. MIT MoCa Team. MOCA: Mobile Telehealth for Rural Communities, 2009.

32. Hall A, Dodd V, et al. Heart failure patients' perception and use of technology to manage disease symptoms. Telemed J E Health. 2014;20(4):323-331.

33. Darkins A, Kendal S, Edmonson E, Young M, Stressel P. Reduced cost and mortality using home telehealth to promote self-management of complex chronic conditions: a retrospective matched cohort study of 4,999 veteran patients. Telemed J E Health. 2015;21(1):71-76.

34. de San Miguel K, Smith J, Lewin G. Telehealth remote monitoring for community-dwelling older adults with chronic obstructive pulmonary disease. Telemed J E Health. 2013;19(9):653-657.

35. National Association of Home Care and Hospice. Basic Statistics About Home Care. Washington, DC: National Association of Home Care and Hospice; 2010. Available from: http://www.nahc.org/assets/1/7/10hc_ stats.pdf. Accessed August 25, 2015.

36. Whittaker F, Wade V. The costs and benefits of technology-enabled home base cardiac rehabilitation measured in a randomized controlled trial. Journal of Telemedicine and Telecare. 2014;20(7):419-422.

37. Jodar-Sanchez F et al. Cost-utility analysis of a telehealth programme for patients with severe chronic pulmonary disease treated with long-term oxygen theraphy. Journal of Telemedicine and Telecare. 2014;20(6):307-316.

38. Bradford $\mathrm{N}$ et al. Internet video to support intravenous medication and administration in the home: a cost minimization study. Journal of Telemedicine and Telecare. 2013;19(7):367-371.

39. Pinnock H, Slack R, Pagliari C, et al. Professional and patient attitudes to using mobile phone technology to monitor asthma. Prim Care Respir J. 2006; $15: 237-245$

40. Martinez-Ramos C, Cerdan MT, Lopez RS. Mobile phone-based telemedicine system for the home follow-up of patients undergoing ambulatory surgery. Telemed J E Health. 2009;15(6):531-537.

41. Kerney H. et al. Evaluation of a mobile phone based, advanced symptom management system (ASmMSC) in the management of chemotherapyrelated toxicity. Support Care Cancer. 2009;17(4):437-444. 
42. The Economist. The doctor in your pocket. The Economist. 2005; 376(8444):8.

43. Mort M, May CR, Williams T. Remote doctors and absent patients: acting at a distance in telemedicine? Sci Technol Hum Val. 2003; 28(2):274-295.

44. Kulkarni S, Agrawal P. Smartphone driven healthcare system for rural communities in developing countries. Paper presented at: Proceedings of the 2nd International Workshop on Systems and Networking Support for Health Care and Assisted Living Environments, June 17, 2008, Breckenridge, CO.

45. Luk R, Ho M, Aoki PM. Asynchronous remote medical consultation for Ghana. Paper presented at: CHI 2008 Proceedings. Healthcare in the Developing World, April 5-10, 2008, Florence, Italy.

46. Wootton R. Telehealth in the Developing World. London, UK: Royal Society of Medicine Ltd; 2009.

47. Jubbawey A. The potential of person centric wireless mobile devices and telehealth solutions: sustaining rising healthcare costs and providing quality care. Paper presented at: Proceedings of Health Informatics, 2009, New Zealand.

48. Agrell H, Dahlerg S, Jerant AF. Patients' perception regarding home telecare. Telemed J E Health. 2000;6(4):409-415.

49. Rahimpour M, Lovell N, Celler B, McCormick J. Patient's perception of a home telecare system. Int J Med Inform. 2007;77(7):486-498.

50. Demiris G, Rantz MJ, Aud M, et al. Older adults' attitudes towards and perceptions of "smart home" technologies: a pilot study. Med Inform Internet Med. 2004;29(2):87-94.

51. Pereira F. Digital Home Survey, 2008-2011. Los Angeles, CA: Institute for Communications Technology Management, Marshall School of Business, University of Southern California; 2011.

52. Fox S, Duggan M. Mobile Health 2012. Available from: http://www. pewinternet.org/files/old-media//Files/Reports/2012/PIP_MobileHealth2012_FINAL.pdf. Accessed August 25, 2015.

53. Gardner-Bonneau D. "Untapped potential: speech technologies and the home health care. Market”. Speech Technology. March 1, 2006. Available from: http://www.speechtechmag.com/Articles/ReadArticle.aspx/ ArticleID=30071. Accessed August 25, 2015.

54. Varshney U. Pervasive healthcare and wireless health monitoring. Mobile Netw Appl. 2007;12:113-127.

55. Lewis C. My computer, my doctor: a constitutional call for federal regulation of cybermedicine. Am J Law Med. 2006;32(4):585-609.

56. Charles B. Telemedicine can lower costs and improve access. Healthc Financ Manage. 2000;54(4):66-69.

57. Wasley TP. What has Government done to our Health Care? Washington, DC: Cato Institute; 1992.

58. Garcia C, Urdiales F, et al. On practical issues about interference in telecare applications based on wireless technologies. Telemed $J E$ Health. 2007;13(5):519-533.

59. Lunden I. Plenty of scope for networking in healthcare industry. Financial Times. February 11, 2008:6.

60. Wartena F. The impact of a personal telehealth ecosystem. Paper presented at: Proceedings of International Conference on eHealth, Telemedicine, and Social Medicine (eTELEMED), 2009; Cancun, Mexico.

61. National Institute of Justice. Implementing telemedicine in correctional facilities. Report number NCJ 190310. Washington, DC, US Department of Justice; 2002

62. Uscher-Pines L, Kahn M. Barriers and facilitators to pediatric emergency telemedicine in the United States. Telemed J E Health. 2014; 20(11):990-996.

63. Hammack G. Redefining Telemedicine. Available from: http://www. healthmgttech.com/archives/1006/1006redefining_telemedicne.htm. Accessed September 20, 2006.

64. Smith D. The influence of financial factors on the deployment of telemedicine. J Health Care Finance. 2005;32(1):16-27.

65. Gagnon M, Lamothe L, Fortin JP, Cloutier A. Telehealth adoption in hospitals: an organizational perspective. J Health Organ Manag. 2005;19(1):32-56.
66. Yang X, Hui C. Mobile Telemedicine: A Computing and Networking Perspective. Boca Raton, FL: CRC Press; 2008.

67. LeRouge C, Tulu B, Forducey P. The business of telemedicine: strategy primer. Telemed J E Health. 2010;16(8):898-909.

68. Statura M. Telemedicine/tele-health: a national development tool and economic engine. Int J Econ Dev. 2006;18(3):679-681.

69. Hoppszallern S. Bridging the distance. HHN Most Wired Magazine. April 2007. Available from: http://www.hhnmostwired.com/hhnmostwired_app/jsp/articledisplay.jsp?dcrpath=HHNMOSTWIRED/ PubsNewsArticlesMostWired/data/07/Winter/07MW_Winter_ DataSet\&domain=HHNMOSTWIRED. Accessed August 25, 2015.

70. Nagy, B. Telemedicine's depth now going beyond rural areas. Manag Healthc Exec. 2006;16(9):62-64.

71. Tangalos EG. Telemedicine: an information highway to save lives. Written testimony to the telemedicine hearing before the subcommittee on investigations and oversight, committee on science, space and technology, US House of Representatives, 103rd Congress, 1994, US Government Printing Office.

72. McCue M, Palsbo S. Making the business case for telemedicine: an interactive spreadsheet. Telemed J E Health. 2006;12(2):99-106.

73. Muirhead, G. An update on telemedicine. Patient Care. 2000;34(6): 90-109.

74. Bowles K, Baugh A. Applying research evidence to optimize telehomecare. J Cardiovasc Nurs. 2007;22(1):5-15.

75. Jodar-Sanchez F, Ortega F, Parra C, et al. Implementation of a telehealth programme for patients with severe chronic pulmonary disease treated with long term oxygen therapy. J Telemed Telecare. 2013; 19(1):11-17.

76. Kothapalli P, Bove A, Santamore W, Homko C, Kashem A. Factors affecting frequency of patient use of internet-based telemedicine to manage cardiovascular disease risk. $J$ Telemed Telecare. 2013;19(4): 205-208.

77. Chen MJ, Chen KY, Chiang SJ, et al. A telehealth service model for the treatment of hypertension. J Telemed Telecare. 2013;19(5):238-241.

78. Sorknase A, Bech M, Madsen H, et al. The effect of real-time teleconsultations between hospital-based nurses and patients with severe COPD discharged after an exacerbation. $J$ Telemed Telecare. 2013;19(8):466-474.

79. Alcherod D. Policy expectations and reality of telemedicine - a critical analysis if health care outcomes, costs and acceptance for congestive heart failure. J Telemed Telecare. 2014;20(4):192-200.

80. Hailey D. The need for cost effective studies in telemedicine. Journal of Telemedicine and Telecare. 2005;11:379-383.

81. Shoor R. Long-distance medicine: telecommunication promises to deliver better care. Bus Health. 1994;12(6):39-40. Available from: http://findarticles.com/p/articles/mi_m0903/is_n6_v12/ai_15496262. Accessed August 25, 2015.

82. Entner R, Lewin D. The impact of the US wireless telecom. Ovum. September 2005.

83. Davalos M, French M, Burdick A, Simmons S. Economic evaluation of telemedicine: a review of the literature and research guidelines for cost-benefit analysis. Telemed J E Health. 2009;15(10):933-948.

84. Schweitzer J, Synowiec C. The Economics of eHealth. Results for Development Institute, 2010.

85. OECD. Improving Health Sector Efficiency: The Role of Information and Communication Technologies. Paris: OECD; 2009.

86. Siu A, Wong RYC. Economic impact of SARS: The case of Hong Kong. Asian Economic Papers. 2004;3(1):62-83.

87. Miller R. Healthcare Business Market Research Handbook. York, UK: Pharmalicensing Limited; 2006.

88. Lohr S. Most doctors aren't using electronic health records. New York Times. June 19, 2008.

89. Latifi R. Current Principles and Practices of Telemedicine and E-Health. The Netherlands: IOS Press; 2008.

90. Iansiti M, Levien R. Strategy as ecology. Harv Bus Rev. 2004: 68-78. 
91. Horowitz A. The real value of VARS: resellers lead a movement to a new service and support. Marketing Computing. 1996;16(4):31-36.

92. Visio A, Pasternak B. Towards a new business model. [webpage on the Internet]. Strategy+Business, 1996; Second Quarter (3). http://www. strategy-business.com/article/14974?gko=9ee07. Accessed August 19, 2016.

93. Timmers P. Business models for electronic markets. Electronic Markets. 1998;8(2):1-6.

94. Markides C. A dynamic view of strategy. Sloan Manage Review. 1999;40(3):55-63.

95. Donath R. Taming e-business models. ISBM business marketing web consortium. 1999;3(1):1-24.

96. Mahadevan B. Business models for Internet-based e-commerce. California Management Review. 2000;42(4):55-69.

97. Gordijn J, Akkermans J, Van Vliet J. Designing and evaluating e-business models. IEEE Intelligent Systems. 2001;16(4):11-7.

98. Linder J, Cantrell S. Changing business models. Chicago: Institute for Strategic Change, Accenture, 2000.

99. Chesbrough H, Rosenbaum R. The role of the business model in capturing value from innovation: Evidence from Xerox Corporation spin-off companies. Industrial and Corporate Change. 2002;11(3):529-555.

100. Gartner [webpage on the Internet]. The Gartner Business Value Model: A Framework for Measuring Business Performance. Available from: https://www.gartner.com/doc/2379317/gartner-business-value-modelframework. Accessed August 19, 2016.

101. Hamel G. Leading the revolution. Harvard Business School Press: Boston; 2001

102. Petrovic O, Kittl C, Teksten R. Developing business models for e-business. [webpage on the Internet]. SSRN Electronic Journal, October 2001; http://papers.ssrn.com/sol3/papers.cfm?abstract_ id $=1658505$. Accessed August 19, 2016.

103. Dubosson-Torbay M, Osterwalder A, Pigneur Y. E-business model design, classification and measurements. Thunderbird International Business Review. 2001;44(1):5-23.
104. Afuah, A, Tucci, C. Internet business models and strategies, McGrawHill International Editions: New York; 2001.

105. Weill P, Vitale M. Place to space. Harvard Business School Press: Boston; 2001.

106. Applegate L. Emerging e-business models. Harvard Business Review 2001;79(1):79-8.

107. Amit R, Zott C. Value creation in e-business. Strategic Management Journal. 2001;22(2):493-520.

108. Alt R, Zimmerman H. Introduction to special section on business models. Electronic Markets. 2001;11(1):3-9.

109. Rayport J, Jaworski B. E-commerce. McGraw-Hill/Irwin: New York; 2001.

110. Betz F. Strategic business models. Engineering Management Journal. 2002;14(1):21-7.

111. Hedman J, Kalling, T. The business model concept: theoretical underpinnings and empirical illustrations. European Journal of Information Systems. 2003;12(1):49-59.

112. Chesbrough H. Business model innovation: opportunities and barriers. Long Range Planning. 2010;43(2/3):354-63.

113. Rappa M. The Utility Business Model and the Future of Computing Services. IBM Systems Journal. 2004;43(1):32-42.

114. Hoyer V, Stanoveska-Slabeva K. Generic business model Types for enterprise mashup intermediaries. Proceedings of the Fifteenth Americas Conference on Information Systems, San Francisco, California. August 6th-9th 2009.

115. Osterwalder A, Pigneur Y. Business Model Generation. 2009, SelfPublished (ISBN 978-2-8399-0580-0).

116. Al-Debei M, Avision D. Developing a unified framework of the business model concept. European Journal of Information Systems. 2010;19 359-376.
Smart Homecare Technology and TeleHealth

\section{Publish your work in this journal}

Smart Homecare Technology and TeleHealth is an international, peer-reviewed, open access online journal publishing original research, reviews, editorials and commentaries on the application of technology to support people and patients at home and in assisted living centers to optimize healthcare and management resources. Specific topics in the journal include: Development and application of

\section{Dovepress}

devices within the home and embedded in appliances; Healthcare provider communication and education tools; and drug ordering and adherence. The manuscript management system is completely online and includes a very quick and fair peer-review system, which is all easy to use. Visit http://www.dovepress.com/ testimonials.php to read real quotes from published authors. 